УДК 821.161.2’06-31Дрозд.09

DOI https://doi.org/10.26661/2414-9594-2021-1-30

\title{
РЕЦЕПЦІЯ РОМАНУ «ВОВКУЛАКА» В. ДРОЗДА В ОЦІНКАХ ЛІТЕРАТУРОЗНАВЦІВ
}

\author{
Гладкова М. В. \\ аспірантка кафедри історії української літератури \\ Харківський начіональний університет імені В.Н. Каразіна \\ майдан Свободи, 4, Харків, Україна \\ orcid.org/0000-0002-0941-6227 \\ 23marinagladkova23@gmail.com
}

\author{
Ключові слова: українська \\ література ХХ століття, \\ літературна критика, \\ химерна проза, індивідуальний \\ стиль, міфологізм, \\ міфопоетика, мотивні \\ домінанти, лікантропія.
}

У статті розглянуто науково-критичні розвідки, присвячені химерній прозі українського письменника В. Дрозда загалом й роману «Вовкулака (Самотній вовк)» (1983 рік) зокрема. 3'ясовано, що зазначений твір є майстерним художнім зразком, який ілюструє риси індивідуального стилю митця, його неповторний, часто парадоксальний та умовний текстосвіт. Звернено увагу на історію написання та проблему видання твору, котра спричинена вимогами тогочасної цензури. Виділено два етапи вивчення твору зі своїми особливостями, а саме радянський та пострадянський; виявлено та систематизовано основні напрями та аспекти вивчення художнього тексту. Перший етап - 3 кінця 1980-х років до 1990-х років - представлений невеликою кількістю статей і характеризується окресленням подальших тем дослідження, а саме поетики характеротворення, авторської концепції, гростескної дійсності (В. Коваль, П. Майдаченко, С. Тримбач). Грунтовною розвідкою цього періоду є робота П. Майдаченка «Поетика умовності у В. Дрозда» [6], у якій автор окреслив основні риси химерних творів митця, звернув увагу на неоміфологізм, символіку образів у текстах.

Другий етап, що триває з 1990-х років, свідчить про те, що увага до вивчення роману «Вовкулака» В. Дрозда значно посилилась (А. Гурбанська, Н. Дашко, М. Жулинський, Н. Манюх, М. Павлишин, О. Січкар, А. Харченко, Л. Яшина). Літературознавці розвивають здобутки попередників та розглядають роман у нових ракурсах. У царині наукових інтересів дослідників цього часу слід назвати міфопоетику твору з екзистенційним підгрунтям, жанрову форму, специфіку реалізації моделей хронотопу, окреслення мотивів (театральності, маскування тощо), автобіографічний пласт, засоби комічного, обігрування митцем традиційного міфу про вовкулаку, надання йому нового звучання.

У ході аналізу було доведено, що дослідження мотивних домінант роману «Вовкулака» є перспективним та потребує подальшого грунтовного вивчення. 


\title{
THE RECEPTION OF THE NOVEL "WEREWOLF" BY V. DROZD IN THE ASSESSMENTS OF LITERARY CRITICS
}

\author{
Hladkova M. V. \\ Postgraduate Student at History of Ukrainian Literature Department \\ V.N. Karazin Kharkiv National University \\ Svobody Square, 4, Kharkiv, Ukraine \\ orcid.org/0000-0002-0941-6227 \\ 23marinagladkova23@gmail.com
}

Key words: Ukrainian literature of the twentieth century, bizarre prose, literary criticism, individual style, mythologism, mythopoetics, motive dominants, lycanthropy.
The paper deals with scientific and critical studies devoted to the bizarre prose of Volodymyr Drozd and the novel "Werewolf (Lone Wolf)" (1983) in particular. The main trends and aspects of the study of the literary text are revealed and systematized. It was found that this work is a masterpiece that illustrates the features of the individual style of the artist, his unique, often paradoxical and conditional text world. Attention is paid to the history of writing and the problem of publishing the work, which is caused by the requirements of contemporary censorship. Two stages of the study of a novel with its own characteristics are highlighteds - Soviet and post-Soviet.

The first stage - from the late 1980s to the 1990s - is represented by a small number of articles and is characterized by outlining further research topics: poetics of characterization, author's concept, grotesque reality (V. Koval, P. Maidachenko S. Trymbach). Thoroughly exploring this period is the work of P. Maidachenko "Poetics of conventionality in V. Drozd" [6], in which the author outlined the main features of bizarre prose of the writer, drew attention to neomythologism, symbols of images in the texts.

The second stage, which lasts from the 1990s to the present day, demonstrates that the attention to the study of the novel "Werewolf" by V. Drozd has increased significantly (A. Hurbanska, N. Dashko, M. Zhulinsky, N. Manyukh, M. Pavlyshyn, A. Sichkar, A. Kharchenko, L. Yashina and others). Literary critics develop the achievements of their predecessors and consider the novel in new perspectives. In the field of scientific interests of researchers - the mythopoetics of a work with an existential basis, genre form, the specifics of the implementation of chronotope models, the outline of motives (theatricality, disguise, and others), an autobiographical layer, means of the comic, the artist's wording of the traditional myth of a werewolf, giving it a new sound.

In the course of the analysis, it is proved that the research of the motive dominants of the novel "Werewolf" is relevant and needs further fundamental research.
«Вовкулака» - самобутній зразок химерної прози В. Дрозда, у якому письменник, послугувавшись міфологічним мотивом лікантропії, репрезентував індивідуально-авторський погляд на проблему існування перевертнів. Історія публікування твору є тривалою та тернистою: письменник почав роботу над текстом у 1960 -х роках, а читач уперше побачив його 1983 року, проте не із заголовком «Вовкулака», а з назвою «Самотній вовк». Пізніше, у 1989 році, прозовий текст увійшов до збірки вибраних творів митця у двох томах [1]. Л. Тарнашинська зазначає щодо перейменування заголовку: «тодішня система не могла допустити художнього втілення думки про те, що в радянському соціумі $\epsilon$ місце для вовків (попри авторову сентенцію, згідно 3 якою «у кожному живе вовк»)» [2, с. 10].
Метою статті є дослідження рецепції роману «Вовкулака» В. Дрозда, окреслення основних етапів вивчення художнього тексту, спільних та відмінних рис цих періодів; виявлення та систематизація підходів до аналізу, з'ясування актуальних аспектів для подальшого дослідження твору.

Перші критичні відгуки на роман датуються 1985 роком. У рецензії «Максималізм» [3] С. Тримбач проводить паралель між життям головного персонажа та явищем летаргічного сну.

Слідом за С. Тримбачем В. Коваль аналізує творчість письменника в розвідках $[4 ; 5]$. У статті «Бачити зорі» автор висвітлює специфіку характеротворення в прозі митця. Критик пише, що герой у В. Дрозда масштабний, «діапазону справді найобширнішого, як і художні засоби, якими він 
відтворюється» [4, с. 155]. Слід зазначити, що літературознавець першим розглядає художні особливості роману «Вовкулака». Він пише про кілька творів автора та відзначає ідейно-тематичну спорідненість «Вовкулаки» й «Балади про Сластьона». Критик констатує, що Андрій Шишига і Йосип Сластьон у своєму переродженні дійшли до трагедії, «вбиваючої все людське» [4, с. 157]. В. Коваль звертає увагу на використання засобів гротеску, сарказму, гіперболізації, через які В. Дрозд розкриває проблеми егоїзму, цинізму та інших людських вад у художніх текстах [4, с. 157]. Загалом літературознавець високо оцінює талант епіка та пише, що його твори порушують злободенні проблеми та не залишають байдужим нікого [4, с. 158$]$.

У 1987 році надруковано грунтовну наукову студію П. Майдаченка «Поетика умовності у В. Дрозда». Дослідник пише про ідейно-тематичну своєрідність творів «Ирій» та «Вовкулака (Самотній вовк)», зазначаючи, що герої «Самотнього вовка» вже переросли свій Ирій [6, с. 18]. Літературознавець акцентує увагу на мотиві роздвоєності в романі, слідом за В. Ковалем наголошує на гротескній дійсності твору: «традиційне гротескове двійництво супроводжується розпадом душі головного героя на дві іпостасі - суть біологічну («вовчу») і людську» [6, с. 18].

П. Майдаченко визначає жанрову форму роману «Вовкулака» як пародію на літературу «неомістицизму» та пише про символіку образу Андрія Шишиги: «єство його вирвалось на волю до натури, від дволикості й фальші» [6, с. 20]. Також автор розвідки аналізує оповідні структури твору, наголошуючи на постійній зміні нарації (з першої на третю особу) як особливості поетики цього прозового тексту.

Отже, загалом критики позитивно оцінили роман; у царині дослідницького аналізу цього часу слід назвати ідейно-тематичне спрямування, проблематику, образну систему твору, засоби характеротворення, художні засоби, акцент на гротескній дійсності, типи оповіді в романі.

У кінці 1990-х та 2000-х роках з'являються якісно нові, перспективні дослідження творчості В. Дрозда загалом й роману «Вовкулака» зокрема. 1999 року опубліковано грунтовні наукові розвідки Н. Фенько [7] та Л. Яшиної [8], присвячені міфопоетичному аналізу прози шістдесятника. Н. Фенько у статті ««Продав би душу оптом, на усі віки...» (інтерпретація міфу про вовкулаку в сучасній українській прозі)» [7] порівнює роман В. Дрозда «Вовкулака» 3 повістю В. Шевчука «Сповідь» та виділяє чотири етапи перетворення людини на вовка, вербалізовані письменниками в цих творах, такі як прокляття, перетворення, випробування й звільнення від прокляття. Авторка акцентує увагу на мотиві перетворення, що репрезентований у творі В. Дрозда композиційним колом, по якому «безупинно рухаються провина і кара» [7, с. 67], на думку літературознавця, це зумовлене задумом митця - обов'язковим покаранням персонажа за бездіяльність. Науковець виділяє засоби характеротворення образу вовкулаки в романі, такі як роздвоєння особистості, лицедійство, самотність у світі людей, мотиви руйнації душі, та зазначає, що митець викриває хворобу сучасності, яка називається «вовкодухістю».

Чимало праць, що висвітлюють прозу В. Дрозда під кутом міфопоетичного аналізу, належить Л. Яшиній $[8 ; 9 ; 10 ; 11]$. Вивчаючи екзистенціальні концепції буття людини в романі «Вовкулака», літературознавець виділяє такі їхні форми, як відчуження, самотність, жах. Вона наголошує на тому, що пристосуванство А. Шишиги пов'язується 3 категорією зла [8, с. 10]. Дослідниця зауважує, що В. Дрозд вибирає межовий образ для відображення «екстремального індивідуалізму» $[8$, с. 10] - перетворення людини на вовка. Маскування, на думку Л. Яшиної, є екзистенційним виявом у творі: «Андрієве обличчя перетворюється на маску, акторство доходить до егоцентризму» $[8$, с. 10$]$.

Науковець тлумачить міфологічні перетворення головного персонажа на вовкулаку через суспільний підтекст, наголошуючи саме на соціальному боці його хижацтва, а саме себелюбстві, заздрощах, наклепництві, користолюбстві, кар'єризмі (криза суспільства): «Перевтілення героя у вовкулаку є алегорією, що підпорядкована виявленню його внутрішнього стану, створенню окремого художнього типу людського характеру» $[8$, с. 11].

Варто відзначити, що у 2000-х роках інтерес дослідників до вивчення ексистенційного підгрунтя прози митця посилився. Так, слідом за Л. Яшиною до цієї проблеми зверталися М. Жулинський, О. Січкар, Л. Тарнашинська та інші вчені.

М. Жулинський відзначає, що в романі «Вовкулака (Самотній вовк)» відбувається метаморфоза 3 пасивного та нерішучого хлопця на «енергійного, агресивного соціального хижака, готового перегризти горло будь-кому на шляху до влади й багатства» $[12$, с. 7]. Дослідник пише, що таке перетворення сталося через моральні компроміси, i це призвело головного персонажа до іпостасі хижого та «безжалісного звіра» [12, с. 8]. Наслідком цього, на думку літературознавця, є «самотність, відчуження від людей, жах перед утратою свого Я, повне духовне спустошення і смерть власної душі» $[12$, с. 8$]$.

Л. Тарнашинська з'ясовує історію написання та видання роману «Вовкулака». Вивчаючи панораму прози автора, вона резюмує, що це «цілий компендіум гріхів і моральних переступів, колек- 
ція людських вад, зламаних характерів, неправедних вчинків i, за великим рахунком, спустошених доль» [2, с. 17-18].

Авторка осмислює екзистенційну проблематику цього художнього тексту, підкреслюючи, що А. Шишига «намагається вичавити 3 міста максимум власних вигод, однак у гонитві за примарним матеріальним щастям зазнає морального краху й душевного спустошення» [2, с. 15]. На думку Л. Тарнашинської, гріхопадіння персонажа починається саме 3 пристосуванства до людей, вищих соціальним щаблем [2, с. 18].

Одним із грунтовних наукових досліджень прози письменника є дисертаційна робота О. Січкар з теми «Проза В. Дрозда: психологічні аспекти» (2008 рік), основні положення якої відтворені в авторефераті [13]. Науковець відзначає звернення письменника до мотиву гри та наголошує на тому, що «у творах химерного плану В. Дрозд намагається 3'ясувати психологію людей-акторів, для яких світ є сценою в театрі, життя - спектакль, а смерть - лише перевдягання за кулісами життєвого театру» [13, с. 10].

Літературознавець доводить, що В. Дрозд у «Вовкулаці» не перекладає відповідальності за вчинки Шишиги на суспільство, а об'єктивно аналізує думки та дії головного персонажа твору, мотивацію його поведінки, подаючи промовистий психологічний портрет типового службовця. О. Січкар наголошує на тому, що автор химерного роману - психолог, який усвідомлює межові ситуації, кризові чинники, що впливають на долю особистості [13, с. 13], тобто заглиблюється в минуле, щоб об’ єктивніше зобразити причини відчуженості Андрія [13, с. 11].

Посутньою науковою думкою, що висунула О. Колодій (Когут) [14], є віднесення роману «Вовкулака» В. Дрозда до жанрової форми притчі. Дисертантка відзначає домінування гротеску та театральності у творі: «Фінальна сцена, у якій головний герой зриває маски з себе і оточуючих, посилює сприйняття роману як притчі, увиразнює його узагальнюючий характер» [14].

О. Когут (Колодій) досліджує мотив гри у творах «Самотній вовк» В. Дрозда та «Плаваюча Євразія» Т. Пулатова [15]; зазначає, що ці прозові зразки належать до «умовного письма» [15, с. 119], та називає їх притчевими. Авторка статті визначає в такий спосіб жанрову природу романів, умотивовуючи це тим, що у «Вовкулаці (Самотньому вовкові)» та в «Плаваючій Свразії» на перший план виходить філософське осмислення вчинків людини, а не морально-дидактичне; персонажі творів $є$ моделями, які діють у сконструйованих ситуаціях за певною схемою відповідно до авторської гри; а часопросторова площина текстів $є$ ускладненою [15, с. 124-125].
Науковець виокремлює два типи художньої театральності, що реалізуються в текстах, а саме саморозкриття і самозміни, і дотримується думки про те, що роман «Самотній вовк» В. Дрозда репрезентує другий іiі вид [15, с. 119].

Предметом дослідницької уваги Н. Дашко, М. Павлишина, О. Січкар та інших науковців стала специфіка часопросторових моделей роману «Вовкулака» В. Дрозда. Літературознавець М. Павлишин у статті «Чому не шелестить «Листя землі»?» [17], уміщеній у монографії «Канон та іконостас» (1997 рік), зосереджує увагу на Пакулі, що згадується в багатьох романах i повістях прозаїка («Спектакль», «Ирій», «Вовкулака», «Листя землі» тощо), а також є важливим для з'ясування специфіки ідеостилю епіка. Він припускається думки про те, що ця лексема походить від поліського діалектизму «покуль», що означає «поки». Автор статті вважає, що топонім Пакуль символізує «кінець тривання теперішнього» [17, с. 279], конкретизуючи це тлумачення в текстах письменника: в «Ирії» - це прагнення вирватися з села в місто, у «Вовкулаці» - вийти 3 рядових посадовців у начальство [17, с. 279].

Слідом за М. Павлишиним О. Січкар резюмує, що, попри той факт, що події цього прозового зразка відбуваються поза межами Пакуля, персонажі, особливо Андрій Шишига, «відчувають на своїх вчинках вплив походження» [17].

У статті «Місто як світ абсурду в романі «Вовкулака» В. Дрозда» Н. Дашко відзначає оригінальну семантизацію та символізацію хронотопу і психологічний характер особистого простору героя $[18$, с. 276]. Авторка дослідження, звертаючись до аналізу екзистенційного пласту твору, зазначає, що «образ міста постає передусім як світ абсурду, зміст якого розкривається через онтологічні модуси самотності й відчуженості < . .> героя та мотив гри (ключовий в естетичній системі постмодернізму)» $[18$, с. 276]. Отже, науковець визначає категорію самотності як чинник екзистенції людини в романі митця. Н. Дашко звертається до аналізу хронотопів роману «Вовкулака» і констатує, що бінарна опозиція «місто - село» набуває «аксіологічно-смислових параметрів морально-вітального протиставлення: місто символізує зло, смерть (духовну і фізичну), образ села у творах В. Дрозда є втіленням гармонійного світу, а концепт лісу - амбівалентний (уособлює і Космос, і Хаос водночас)» [18, с. 281].

Необхідно відзначити, що дослідники не оминули аналізу засобів комічного творчого доробку В. Дрозда, що втілюються на всіх рівнях його художніх текстів. Одним із перших літературознавців, хто звернув увагу на сатиричну спрямованість творів митця, є М. Павлишин [16].

Авторами грунтовних праць щодо окресленої теми є А. Гурбанська [19], А. Харченко 
[20; 21; 22]. Предметом аналізу дисертаційної роботи А. Харченко, основні положення якої вміщені в авторефераті [20], є образ головного персонажа роману «Вовкулака»; дослідниця визначає постать Андрія як представника іронії нігілізму $[20$, с. 9]. Вона звертає увагу на те, що Шишига заперечує моральні цінності, намагаючись задовольнити всі свої бажання, що особливо показово виявляється в його стосунках із чужою дружиною, де Андрій яскраво показує свою тваринну природу: «Іронія в поведінці Шишиги в цьому випадку постає як погоня за насолодами, в якій він втрачає контроль над собою» [20, с. 9]. В. Дрозд у творі використав міф про вовкулаку, «у своєрідній формі показав внутрішній конфлікт між людським і звірячим началом у душі героя, примирення яких так і не відбулося», - резюмує науковець [20, с. 9].

А. Гурбанська визначає риси поетики творів В. Дрозда, такі як гумор, іронія, сатира, гротеск. Також вона виділяє шар фольклорно-фантастичних елементів, що притаманні прозі митця, а саме небилицю, міфообраз, міфометафору, алегорію, травестію, легенду, сказання [19, с. 206]. Авторка пише, що герой роману «Вовкулака» та персонажі інших творів епіка («Спектакль», «Балада про Сластьона», «Злий дух. Із житієм», «Катастрофа») втрачають себе, духовно спустошуються, коли вдовольняють егоїстичні потреби, вивищуюються над іншими [19, с. 207].

Необхідно зазначити, що поетику роману «Вовкулака» увиразнюють ономастичні реалії, які письменник майстерно репрезентує в тексті. Першою дослідницею, яка всебічно проаналізувала специфіку реалізації власних назв у творах митця, є Л. Шестопалова. У статті «Антропонімія роману В. Дрозда «Вовкулака (Самотній вовк)»»» вона пише про те, що прізвище головного персонажа розкриває його психологію. Науковець зазначає, що письменник умисно не коментує значення прізвища Шишига: «воно старанно замуроване» [23, с. 199], і тільки через відповідні обставини (роздвоєння особистості, прояв звіриних інстинктів тощо) ця назва стає зрозумілою читачеві (Шишига - злий дух). Думку Л. Шестопалової розвиває М. Жулинський, вказуючи на те, що шишигою слов'яни традиційно називали злого духа, нечисту силу. М. Жулинський вважає, що промовисте прізвище персонажа «Вовкулаки» покликане ще раз підкреслити, що негативні вияви натури не зникають із часом, а просто трансформуються, набуваючи нових форм $[12$, с. 7$]$.
Чимало наукових праць, присвячених вивченню химерного епосу письменника, належать Н. Манюх [24; 25; 26]. Предметом досліджень літературознавця $є$ специфіка характеротворення у В. Дрозда та автобіографічний контекст його художніх текстів. Вона слушно підкреслює, що «у «Вовкулаці (Самотньому вовкові)», як і в багатьох твоpax, письменник основну увагу зосереджував на так званій викривленій особистості з її трагедією роздвоєння душі, віддзеркалюючи психологію абсурдного суспільства «розвиненого соціалізму», психологію справді нової людини, яку виховали комуністичні експериментатори» [24, с. 215]. 3вертаючись до компаративного аналізу перекладів та оригіналу роману у статті [24], Н. Манюх звертає особливу увагу на такі засоби характеротворення у творі «Вовкулака», як мовлення, портретні характеристики, інстинктивні рухи [24, с. 216-217].

Дослідивши рецепцію творчості В. Дрозда, ми виявили два етапи вивчення роману «Вовкулака». Перший етап тривав 3 кінця 1980-х років до 1990-х років і представлений невеликою кількістю статей. Критики В. Коваль, С. Тримбач, П. Майдаченко звернули увагу на змістові чинники, поетику характеротворення, авторську концепцію, гротескну дійсність твору.

Другий етап вивчення художнього тексту з 1990-ті років - засвідчує, що увага до твору «Вовкулака» В. Дрозда значно посилилась. Літературознавці розвивають здобутки попереднього періоду та у зв'язку з появою перспективних методик зосереджують увагу на новому, а саме розглядають доробок письменника крізь призму міфопоетики (Н. Фенько, Л. Яшина), автобіографізму (Н. Манюх), часопросторових площин (Н. Дашко, М. Павлишин, О. Січкар), іронії як вияву авторської свідомості та стильового елемента творчості прозаїка (А. Харченко), інших засобів комічного (А. Гурбанська), психологізму, екзистенціалізму (М. Жулинський, О. Січкар, Л. Яшина), ігрового начала текстів митця (О. Когут, А. Харченко); також здійснена спроба класифікувати жанрову форму роману як новітню притчу (О. Колодій).

До розгляду поетики мотиву у творчості В. Дрозда звертались Н. Дашко, О. Когут, О. Січкар, Н. Фенько, А. Харченко, проте досі відсутня грунтовна розвідка щодо окресленого питання. Отже, незважаючи на те, що твір перебував у колі наукових інтересів літературознавців, цей аналіз засвідчує, що дослідження художнього світу майстра $є$ перспективним, зокрема в аспекті вивчення реалізації та специфіки мотивних домінант у романі «Вовкулака».

\section{ЛІТЕРАТУРА}

1. Дрозд В. Вибрані твори : у 2 т. ; вст. ст. В. Дрозда. Київ : Радянський письменник, 1989. Т. 1 : Крик птаха у сутінках. Катастрофа. Вовкулака (Самотній вовк). 462 с. 
2. Тарнашинська Л. Володимир Дрозд: «Письменник - лише уста народу» : біобібліографічний нарис / бібліографи-упорядн.: Г. Волянська, Т. Заморіна ; наук. ред. І. Негрейчук. Київ : Міністерство культури України, Національна парламентська бібліотека України, 2013. Вип. 15. 176 с.

3. Тримбач С. Максимализм. Дружба народов. 1985. № 6. С. 256-258.

4. Коваль В. Бачити зорі: проза В. Дрозда. Вітчизна. 1987. № 4. С. 153-157.

5. Коваль В. Письменник жорсткий, колючий. Літ. Україна. 1989. 24 серпня. С. 6.

6. Майдаченко П. Поетика умовності у В. Дрозда. Рад. літературознавство. 1987. № 2. С. 15-23.

7. Фенько Н. Продав би душу... Слово $і$ час. 1999. № 8. С. 66-70.

8. Яшина Л. Міфопоетика епіки В. Дрозда : автореф. дис. ... канд. філол. наук : спец. 10.01.01. Дніпропетровськ, 1999. 19 с.

9. Яшина Л. Інтерпретація фольклорного мотиву в повісті В. Дрозда «Вовкулака» («Самотній вовк»). Нове прочитання забутих сторінок української літератури : збірник наукових праць. Дніпропетровськ : ДДУ, 1996. С. 81-86.

10. Яшина Л. Опозиція людина - не-людина в романах «Под знаком сверчка» В.В. Савченка та «Вовкулака» В.Г. Дрозда. Актуальні проблеми слов'янської філології. 2008. Вип. XV. С. 203-208.

11. Яшина Л. Своєрідність вираження опозиції добро - зло у творчості В. Дрозда. Актуальні проблеми літературознавства : збірник наукових праць / наук. ред. Н. Заверталюк. Т. 3. Дніпропетровськ : Навчальна книга, 1998. С. 103-108.

12. Жулинський М. Острів у вічності був обіцяний Майстрові ще на землі (до 70-річчя Володимира Дрозда). Слово і час. 2009. № 10 (586). С. 3-9.

13. Січкар О. Проза В. Дрозда: психологічні аспекти : автореф. дис. ... канд. філол. наук : спец. 10.01.01. Херсон, 2008. 20 c.

14. Колодій О. Притча і притчевість в українській прозі 70-80-х років XX ст. : автореф. дис. ... канд. філол. наук : спец. 10.01.06. Київ, 2000. 16 с. URL: http://referatu.net.ua/referats/7569/178605 (дата звернення: 20.04.2021).

15. Когут О. Мотив гри як чинник моделювання узагальнених ситуацій у притчевих творах (В. Дрозд «Самотній Вовк», Т. Пулатов «Плаваюча Євразія»). Studia Methodologica : науковий збірник / гол. ред. О. Лещак; відп. ред І. Папуша; редкол.: Є. Адамчик, М. Братасюк, О. Глотов, Р. Гром'як та ін. Вип. 15. Тернопіль : ТНПУ, 2005. С. 119-125.

16. Павлишин М. Чому не шелестить «Листя землі?». Канон та іконостас: літературно-критичні статті. Київ : Час, 1997. С. 276-292.

17. Січкар О. Жанрово-стильове розмаїття прози В. Дрозда. URL: http://eprints.zu.edu.ua/1905/1/5.pdf (дата звернення: 24.03.2021).

18. Дашко Н. Місто як світ абсурду в романі «Вовкулака» В. Дрозда. Актуальні проблеми слов янської філології. Серія: Лінгвістика і літературознавство. 2010. Вип. ХХІІІ. Ч. 3. С. 275-282.

19. Гурбанська А. Гумористично-сатирична парадигма у творчості Володимира Дрозда. Науковий часопис Начіонального педагогічного університету імені М. Драгоманова. Серія 8: Філологічні науки (мовознавство і літературознавство) : збірник наукових праць. Вип. 7. Київ : вид-во НПУ імені М. Драгоманова, 2017. С. 206-216.

20. Харченко А. Іронія як стильовий компонент прози Володимира Дрозда : автореф. дис. ... канд. філол. наук : спец. 10.01.01. Харків, 2008. 19 с.

21. Харченко А. Міфологізм і сміхове начало у прозі В. Дрозда: до проблеми рецепції творів письменника українською літературною критикою. Вісник Харківського національного університету ім. В. Каразіна. Серія: Філологія. 2007. Вип. 50. № 765. С. 167-171.

22. Харченко А. Самоіронія як вияв авторської свідомості (повість-шоу В. Дрозда «Музей живого письменника...»). Вісник Харківського наџіонального університету ім. В. Каразіна. Серія: Філологія. 2008. Вип. 50. № 798. С. 180-185.

23. Шестопалова Л. Антропонімія роману В.Г. Дрозда «Вовкулака» («Самотній вовк»). Науковий вісник Ізмаїльського державного гуманітарного університету. 2002. Вип. 12. С. 198-202.

24. Манюх Н. Особливості перекладів роману «Вовкулака (Самотній вовк)» В. Дрозда російською та польською мовами. Вісник Житомирського державного університету імені I. Франка. 2014. Вип. 4. С. 214-219.

25. Манюх Н. Автобіографізм як особливість характеротворення у прозі Володимира Дрозда. Слово і час. 2008. № 5. С. 81-87.

26. Манюх Н. Поетика характеротворення у прозі В. Дрозда : автореф. дис. ... канд. філол. наук : спец 10.01.01. Івано-Франківськ, 2008. 18 с. 


\section{REFERENCES}

1. Drozd V. (1989) Vybrani tvory [Selected works]. Vol. 1. Kryk ptakha u sutinkakh. Katastrofa. Vovkulaka (Samotnii vovk). K.: Rad. pysmennyk.

2. Tarnashinska L. (2013) Volodymyr Drozd: "Pysmennyk - lyshe usta narodu": biobibliohr. narys [Volodymyr Drozd: «The writer is only the mouth of the people»: Biobibliogr. essay]. vol. 15, K.: M-vo kultury Ukrainy, Nats. parlam. b-ka Ukrainy.

3. Trymbach S. (1985) Maksymalyzm [Maximalism]. Druzhba narodov, no. 6, pp. 256-258.

4. Koval V. (1987) Bachyty zori: proza V. Drozda [To see the stars: prose by V. Drozd]. Vitchyzna, no. 4, pp. $153-157$.

5. Koval V. (1989) Pysmennyk zhorstkyi, koliuchyi [The writer is hard, prickly]. Lit. Ukraina, 24 serp. P. 6.

6. Maidachenko P. (1987) Poetyka umovnosti u V. Drozda [Poetics of conventionality in V. Drozd]. Rad. literaturoznavstvo, no. 2, pp. 15-23.

7. Fenko N. (1999) Prodav by dushu... [I would sell my soul...]. Slovo i chas, no. 8, pp. 66-70.

8. Yashyna L. (1999) Mifopoetyka epiky V. Drozda [V. Drozd's Mythological Poetics of Epics] (PhD Tesis), D., 1999.

9. Yashyna L. (1996) Interpretatsiia folklornoho motyvu v povisti V. Drozda "Vovkulaka" ("Samotnii vovk") [Interpretation of folk motive in the novel of V. Drozd "Werewolf" ("Lone Wolf")]. Nove prochytannia zabutykh storinok ukrainskoi literatury [A new reading of forgotten pages of Ukrainian literature]. D.: DDU, pp. 81-86.

10. Yashyna L. (2008) Opozytsiia liudyna - ne-liudyna v romanakh "Pod znakom sverchka" V.V. Savchenka ta "Vovkulaka" V.H. Drozda [Human - non-human opposition in the novels "Under the Sign of the Cricket" by V.V. Savchenko and "Werewolf" by V.H. Drozd]. Aktualni problemy slov'ianskoi filolohii, vol. 15 pp. 203-208.

11. Yashyna L. (1998) Svoieridnist vyrazhennia opozytsii dobro-zlo u tvorchosti V. Drozda [Peculiarity of the expression of the opposition of good and evil in V. Drozd's prose]. Aktualni problemy literaturoznavstva [Current issues of literary studies]. D.: Navchalna knyha, vol. 3, pp. 103-108.

12. Zhulynskyi M.(2009) Ostriv u vichnosti buv obitsianyi Maistrovi shche na zemli (do 70-richchia Volodymyra Drozda) [An isle in eternity was promised to the Master when he was still alive (In commemoration of Volodymyr Drozd's 70th anniversary)]. Slovo i chas, no. 10 (586), pp. 3-9.

13. Sichkar O. (2008) Proza V. Drozda: psykholohichni aspekty [Prose of V. Drozd: the psychological aspects] (PhD Thesis), Kherson: Khersonskyi derzh. un-t.

14. Kolodii O. (2000) Prytcha $i$ prytchevist v ukrainskii prozi 70-80-kh rokiv XX st. [Parabola and parabolality in Ukrainian prose of $70-80^{\text {th }}$ of rhe $20^{\text {th }}$ centuary] (PhD Thesis), K.: NAN Ukrainy, In-t l-ry im. T. Shevchenka. Retrieved from: http://referatu.net.ua/referats/7569/178605 (accesed 8 April 2021).

15. Kohut O. (2005) Motyv hry yak chynnyk modeliuvannia uzahalnenykh sytuatsii u prytchevykh tvorakh (V. Drozd "Samotnii Vovk", T. Pulatov "Plavaiucha Yevraziia") [The motive of the game as a factor in modeling general situations in parables (V. Drozd "Lone Wolf", T. Pulatov "Floating Eurasia")]. Ternopil: TNPU, vol. 15, pp. 119-125.

16. Pavlyshyn M. (1997) Chomu ne shelestyt "Lystia zemli"? [Why don't the rustle "Lives of the Earth"?]. Kanon ta ikonostas: Literaturno-krytychni statti [Canon and Iconostasis: literary-critical articles]. K.: Chas, pp. 276-292.

17. Sichkar O. (2006) Zhanrovo-stylove rozmaittia prozy V. Drozda [Genre-style variety of V. Drozd's prose]. VISNYK Zhytomyrskoho derzhavnoho universytetu imeni Ivana Franka, no. 28, pp. 199-204. Retrieved from: http://eprints.zu.edu.ua/1905/1/5.pdf (accesed 10 April 2021).

18. Dashko N. (2010) Misto yak svit absurdu v romani "Vovkulaka" V. Drozda [The city as a world of absurdity in V. Drozd's novel "Werewolf”]. Aktualni problemy slov'ianskoi filolohii. Seriia: Linhvistyka i literaturoznavstvo: Mizhvuz. zb. nauk. st, vol. XXIII, part. 3, pp. 275-282.

19. Hurbanska A. (2017) Humorystychno-satyrychna paradyhma u tvorchosti Volodymyra Drozda [Humorous and satirical paradigm in the work of Volodymyr Drozd]. Naukovyi chasopys Natsionalnoho pedahohichnoho universytetu imeni M. P. Drahomanova. Seriia 8: Filolohichni nauky (movoznavstvo i literaturoznavstvo), vol. 7, pp. 206-216.

20. Kharchenko A. (2008) Ironiia yak stylovyi komponent prozy Volodymyra Drozda [The irony as a style component of Volodymyr Drozd's prose] (PhD Thesis), Kh: Khark. nats. un-t im. V. Karazina.

21. Kharchenko A. (2007) Mifolohizm i smikhove nachalo u prozi V. Drozda: do problemy retseptsii tvoriv pysmennyka ukrainskoiu literaturnoiu krytykoiu [Mithologism and a laughing tone in prose by V. Drozd: to the problem of the reception of the writer's works by Ukrainian literary criticism]. Visn. Khark. nats. un-tu im. V. Karazina. Ser.: Filololohiia, vol. 50, no. 765, pp. 167-171. 
22. Kharchenko A. (2008) Samoironiia yak vyiav avtorskoi svidomosti (povist-shou V. Drozda "Muzei zhyvoho pysmennyka..." [Self-irony as a manifestation of the author's consciousness (the novel-show "Museum of the Living Writer..." by V. Drozd.]. Visn. Khark. nats. un-tu im. V. N. Karazina. Ser.: Filolohiia, vol. 50, no. 798 , pp. $180-185$.

23. Shestopalova L. (2002) Antroponimiia romanu V.H. Drozda "Vovkulaka" ("Samotnii vovk") [Anthroponymy of V. Drozd's novel "Vovkulaka" ("Lone Wolf")]. Izmail: Nauk. visn. Izmail. derzh. humanitar. un-tu, vol. 12, pp. 198-202.

24. Maniukh N. (2014) Osoblyvosti perekladiv romanu "Vovkulaka (Samotnii vovk)" V. Drozda rosiiskoiu ta polskoiu movamy [Peculiarities of Russian and Polish Translations of V. Drozd's Novel "Lone Wolf"]. VISNYK Zhytomyrskoho derzhavnoho un-tu imeni I. Franka, vol. 4, pp. 214-219.

25. Maniukh N. (2008) Avtobiohrafizm yak osoblyvist kharakterotvorennia u prozi Volodymyra Drozda [Autobiographysm as a feature of characterization in the prose by Volodymyr Drozd]. Slovo i chas, no. 5, pp. 81-87.

26. Maniukh N. (2008) Poetyka kharakterotvorennia u prozi V. Drozda [Poetics of characterization in the prose by V. Drozd] (PhD Thesis), Ivano-Frankivsk: Prykarpat. nats. un-t im. V.Stefanyka. 